\title{
Using Mobile Phone to Overcome Students' Anxiety in Speaking English
}

\author{
Karmila Machmud ${ }^{1, *}$, and Ridwan Abdulah $^{2}$ \\ ${ }^{1}$ English Department, Faculty of Letters and Culture, Universitas Negeri Gorontalo, Indonesia \\ ${ }^{2}$ SMP Negeri 5 Anggrek Gorontalo Utara, Provinsi Gorontalo, Indonesia
}

\begin{abstract}
The goal of this research is to discover whether the use of mobile phone can minimize students' anxiety in speaking English and in turn will improve their speaking skill. Anxiety has become a major problem for students when asked to speak in a speaking class. Using quasi experimental method, the data of this research was collected through questionnaire of foreign language anxiety classroom scale, and oral test for speaking ability. Factorial design $2 \times 2$ using ANOVA is used to analyze the data of this research. The result has shown: (1) the score of students' learning achievement in speaking English who were taught by using mobile phone application was higher than the students' who were taught by using conventional teaching. It means that the use of mobile phone application results in better influence towards students' speaking ability; (2) The learning achievement of the students with high anxiety in speaking English who were taught by using mobile phone application was higher than the high-anxiety students who were taught by conventional teaching; (3) The learning achievement in speaking English of low anxiety students who were taught by using mobile phone application was higher than low anxiety students' who were taught by conventional teaching.
\end{abstract}

Key Words: students'anxiety, mobile phone application, mobile technology

\section{Introduction}

Some problems that appear in teaching speaking are; first, the time allocation is too little, and second, is the anxiety. Such in tenth standard competence at seventh grade, in two meetings or in 4 X 40 minutes of teaching process, the students are asked to describe something/someone with their own words orally in front of the class. Then in the second meeting, the students are asked to tell their friends how to do or to make something.

From the explanation above, it can be concluded that the teaching and learning process is not effective, because in such limited time allocated, the teacher should explain the material and then guide the students to pronounce some words. Thus, it left with almost no time for other important learning activities. Teacher has 80 minutes. In that length of time, for example, 30 minutes is used for explaining the material, 5 minutes for guiding the students to pronounce the difficult words, 5 minutes for preparing the students presentation,

${ }^{*}$ Correspondingauthor: karmila.machmud@ung.ac.id 
and 40 minutes for the presentation. It is obvious that that the times allocated for each activities are not sufficient enough to build students' speaking skill.

In such a short length of time students are pushed to practice speaking in front of the class with a very limited time to prepare. This makes it difficult for them to control their anxiety. The anxiety and worry are associated with three or six symptoms that can be noticed from the students [1]. These problems can be minimized by using Information and Communication Technology (ICT) tool, because studies show that ICT has a positive influence towards students learning process. The ICT tools include computers, radio, television, mobile phone and some other devices. Among the ICT tools that is mostly owned and widely used is mobile phone. The report from the statistic portal shows that the total number of mobile phone users worldwide from 2013 to 2019 shows a significant increase of the mobile phone users from only 4.05 billion in 2013 to 4.77 billion in 2017, and it is predicted that the number will climb to 5.07 billion users in 2019 .

Teacher can use this as a potential of improving the teaching and learning processes, because of the availability of this device which is owned by students; thus, this can be considered as cheap technological tool compared to other ICTs, which can be used for teaching and learning [2]. Mobile phone became one of the tools that can be useful in teaching process because most of the students are familiar with the use of mobile phone in their daily live.

Based on the above arguments, we decided to choose SMP Negeri 1 Anggrek as our subject of research. SMP Negeri 1 Anggrek is located at Tolanggo Village, Aggrek subdistrict, Gorontalo Utara regency. The students of SMP Negeri 1 Anggrek come from various villages on the island. The parents'jobs are mostly farmers, fishermen, and civil servants. There are 53 students of seventh grade of SMP Negeri 1 Anggrek, and 29 students out of them usually bring their mobile phones to school. Unfortunately, they do not use it as a learning aid, instead they are busy using it for playing game like face booking, chatting and some other activities that distract them from learning. I think this is happened because teacher does not have a clear design of how to integrate the use of mobile phone in the teaching learning process; thus, in this research I would like to describe how the students use their mobile phones in the instructional process, especially in teaching speaking.

There are some interesting ways of using mobile phone in teaching and learning process, especially in teaching speaking. Some features in mobile phone that can be used in this project are mobile video, voice recorder, a digital storytelling tool, or class video projects. For example, teacher can assign students in different groups. Then each group will create their own video project.

The other advantage of using the features in mobile phone is that the teacher can use the video to assess students' speaking skills, also, can use the video as a document of the students' project, which is in turn can give feedback on their speaking skill.

Many students who have mobile phones have the ability to record video. Then once video sent to you via Bluetooth/cable/wi-fi/other network, you can place on LAN or share to class via YouTube or Facebook. This can then be added to a class blog, added to an intranet/ VLE. When students use video cameras themselves they are given a potential to create something memorable and enjoyable. The task of video-making can provoke genuinely creative and communicative uses of the language, with students finding them doing new things in English [3].

Besides video, the voice recorder's feature can also be used as a means of collecting audio evidence, feedback on work. This can be done by adding the voice recorder to portfolio as evidence of peer feedback, learning, development transfer to machine via Bluetooth, Wi-Fi, email, and link up by embedding, storing on intranet etc. Voice recorder could be used for other purposes too such as: interview, recording instructions, podcast

"Correspondingauthor: karmila.machmud@ung.ac.id 
style notes and keywords for revision. Most mobile phone can also record a voice. Children and young learners use their mobile phone to record their voice, watch and exchange videos.

The other activity which can be conducted is Class Video Project. This activity has some instructions firstly, invite students to prepare a minute video in class, then they may prepare, negotiate, discuss, and plan for their project based on the class time, once they are ready, they use one mobile device to record their video. Then, they can share the video file with the teacher using blue-tooth. The whole class can watch those videos using the class projector for feedback and follow-up discussions. Class video project or video creativity can be used to spark students' creativity by encouraging interpretation, provoking thought, asking for language use [3].

\section{Methodology}

The method of this study is experimental method. In conducting this study, we used quasi experiment. Quasi experiment is a development study of true experiment design [6]. This study was conducted at the seventh grade students of SMP Negeri 1 Anggrek in 2015/2016 academic years. Sixty three participants were given the questionnaire of foreign language anxiety classroom scale to determine their level of anxiety; the results were 20 students who were grouped into high anxiety students, and 20 students as low anxiety students. A number of 13 students who fell into the medium anxiety category were not selected for the experiments. The high and low anxiety groups were then given oral test for measuring their speaking ability. The design of this study was 2 × 2 factorial design. The independent variable was mobile phones application $\left(A_{1}\right)$ and conventional teaching $\left(A_{2}\right)$. While the attribute variable was anxiety involve high anxiety $\left(B_{1}\right)$ and low anxiety $\left(B_{2}\right)$.

\section{Results and Discussion}

\subsection{Results}

The findings discuss about the data description of the study, the data analysis of requirement and the homogeneity test.

This section described the data of the students' learning achievement in speaking English after being taught by using mobile phone. The data are presented in eight groups, as follows: (1) The data of students' learning achievement in speaking English who were taught by using mobile phone (A 1); (2) The data of students' learning achievement in speaking English who were taught by using conventional teaching (A 2); (3) The data of students' learning achievement in speaking English who have high anxiety (B 1); (4) The data of students' learning achievement in speaking English who have low anxiety (B 2); (5) The data of students' learning achievement in speaking English who have high anxiety taught by using mobile phone (A1 B1); (6) The data of students' learning achievement in speaking English who have low anxiety taught by using mobile phone (A1 B2); (7) The data of students' learning achievement in speaking English who have high anxiety taught by using conventional teaching (A2 B1) and (8) The data of students' anxiety in speaking English who have low anxiety taught using conventional teaching (A2 B2).

The data description that was obtained in this study can be seen further from the Table 1.

*Correspondingauthor: karmila.machmud@ung.ac.id 


\subsection{Discussion}

Table 1 shows the data findings of students' learning achievement in speaking English. The complete discussions and analysis of the results of this research are as follow.

\subsubsection{Students' Learning achievement in speaking English who are taught by using mobile phone application and conventional teaching}

The students' learning achievement in speaking English who were taught by using mobile phone application is higher than the students' speaking English who were taught by conventional teaching. It means that using mobile phone application has a better influence towards students' speaking English than using conventional teaching. Using mobile phone application especially video and voice recorder in teaching speaking helps both the teacher and students. The teacher uses fewer times than when using conventional teaching. Then for the students, they enjoy the learning process more than they enjoy the conventional teaching. Students are interested and more motivated to learn.

When students use video cameras themselves they are given potential to create something memorable and enjoyable [3]. Using mobile phone's features, especially video and voice recorder, in teaching and learning process provides opportunity for the students to edit, submit, and re-edit again to make it perfect, the process per se will give more opportunity to the students to improve their speaking skill.

Table 1. The data description of students' learning achievement in speaking English

\begin{tabular}{|c|c|c|c|c|c|c|c|c|}
\hline \multirow{2}{*}{$\begin{array}{l}\text { Data } \\
\text { Group }\end{array}$} & \multirow[b]{2}{*}{$\mathrm{N}$} & \multirow[t]{2}{*}{ Score Min } & \multirow{2}{*}{$\begin{array}{c}\text { Score } \\
\text { Max }\end{array}$} & Mean & Modus & Median & $\begin{array}{c}\text { St. } \\
\text { dev. }\end{array}$ & Variants \\
\hline & & & & $(\overline{\mathrm{X}})$ & (Mo) & $(\mathrm{Me})$ & (S) & $\left(\mathrm{S}^{2}\right)$ \\
\hline A1 & 20 & 9 & 19 & 14.20 & 15.16 & 14.5 & 3.06 & 9.38 \\
\hline $\mathrm{A} 2$ & 20 & 8 & 16 & 12.10 & 12.84 & 12.5 & 2.39 & 5.73 \\
\hline B1 & 20 & 8 & 18 & 12.40 & 14.08 & 11.5 & 2.86 & 8.20 \\
\hline $\mathrm{B} 2$ & 20 & 9 & 19 & 13.80 & 12.64 & 12.7 & 2.99 & 8.96 \\
\hline A1 B1 & 10 & 9 & 18 & 14.70 & 13.5 & 13.16 & 2.63 & 6.93 \\
\hline A1 B2 & 10 & 10 & 19 & 15.30 & 16.7 & 16 & 2.70 & 7.29 \\
\hline A2 B1 & 10 & 8 & 15 & 12.30 & 13.7 & 13.5 & 2.70 & 7.29 \\
\hline A2 B2 & 10 & 9 & 16 & 12.30 & 12.7 & 12.84 & 2.57 & 6.62 \\
\hline
\end{tabular}

\subsubsection{Interaction between the model of teaching and students' anxiety level toward students' speaking English}

The application of suitable model of teaching by considering the students' anxiety level gave an effect towards students' speaking English. It needs a way to overcome the anxiety level. The model of teaching by using mobile phone application and conventional teaching can reduce the students' anxiety level. 
Using mobile phone application in English teaching and learning process, especially in teaching speaking enticed the students to perform their competence to communicate their idea.

Using videos into lessons creates enticing visuals and a special interactive environment in the EFL/ESL classroom [5]. Teaching English through videos also allows teachers to be creative when designing language lessons [3]. There are some reasons of using video in teaching and learning process; they are: seeing language-in-use, cross-cultural awareness, the power of creation, and motivation.

The use of mobile phone application gave positive effect, and motivated the students to be more creative. It was shown from the result of the students' scores in speaking English. The students who were taught by using mobile phone application got higher scores than the students who were taught by conventional teaching.

\subsubsection{The learning achievement of students who have high anxiety in speaking English, and were taught by using mobile phone application and by conventional teaching}

The students' learning achievement in speaking English who have high anxiety, and taught by using mobile phone application, got higher score than the students who were taught by using conventional teaching technique. It means that there is a difference of students' learning achievement in speaking English between those taught by using mobile phone application, and those who were taught by using conventional teaching.

The students who were taught by using mobile phone application were more likely to engage in the learning process, and have more fun than the students who were taught by using conventional teaching. The students who were taught by using conventional teaching tend to show unconcerned to the material. They were panic, sweating, trembling and shaking their body. There are five main types of anxiety disorder; one of them is panic disorder: The focus here is on attacks of panic that appear to come on for no reason ('out of the blue'). Involving racing heartbeat (palpitations), chest pain, sweating, trembling and shaking, many people fear that they are having a heart attack or stroke, dying or going mad [7].

\subsubsection{The learning achievement of students who have low anxiety in speaking English, and were taught by using mobile phone application and by conventional teaching}

The English speaking achievements of the students who have low anxiety and taught by using mobile phone application were higher than the achievements of the students taught by using conventional teaching technique. It means that there is a difference of students' anxiety in speaking English between students who were taught by using mobile phone application and students who were taught by using conventional teaching technique.

Bailey's in [4] defined that anxiety in second language learning was the key to success. Anxiety causes many potential problems to the students who were learning foreign language. It does not mean that the students' anxiety cannot be reduced. The students' anxiety can be reduced by using a suitable method in teaching and learning process.

"Correspondingauthor: karmila.machmud@ung.ac.id 


\section{Conclusions and Recommendation}

\subsection{Conclusion}

Based on the findings and discussion presented, it can be concluded that: first, there is a difference of the students' learning achievement in speaking English when they were taught by using mobile phone; second, the students who have high anxiety tend to achieve higher score when they were taught by using mobile phone; and finally, even the students who have low anxiety tend to obtain higher learning achievement when they were taught by using mobile phone.

\subsection{Recommendation}

Considering that using mobile phone can give a positive effect towards both groups of high and low anxiety students, it is highly recommended that teacher should begin to integrate the use of mobile phone in teaching and learning English as a foreign language in an attempt to minimize students' anxiety, which will eventually increase their learning achievement in speaking English.

We would like to express our gratitude towards all people and institutions that support this research. The first is the government of Gorontalo Utara regency, which has given us the opportunity to conduct this research in one of the schools in the regency. Our gratitude also goes to Universitas Negeri Gorontalo, where we got lots of sources which support our research.

We also want to express our gratitude to the committee and the reviewer who give us the opportunity to present our paper in Global Conference on Teaching, Assessment, and Learning in Education (GC-TALE) in Bali, 28-29 August 2017

\section{References}

1. T. Brown, T. A. O'Leary, D.H. Barlow (ed), Generalized anxiety disorder. Clinical handbook of psychological disorders, third edition: A step-by-step treatment manual. (Guilford Publications, 2001)

2. P. W. Mtega, R. Bernard, A. Msungu, Sanare, R., Using Mobile Phones for Teaching and Learning Purposes in Higher Learning Institutions: the Case of Sokoine University of Agriculture in Tanzania. Morogoro - Tanzania (Sokoine University, 2012).

3. J. Harmer, The practice of english language teaching (Longman: Cambridge, 2004)

4. H. D. Brown, Principles of language learning and teaching (Addison Wesley San Fransisco: Longman ,2000)

5. S.Yassaei, Using original video and sound effects to teach English. English teaching forum (United Kindom, 2012)

6. Sugiono, Metode penelitian kuantitatif kualitatif dan $R \& D$. (Alfabeta:Bandung, 2014)

7. T. Dixon, Understanding anxiety problem. (Help-For,2011) 